\title{
Pullulan Production by Aureobasidium pullulans ATCC 201253 Cells Adsorbed onto Cellulose Anion and Cation Exchangers
}

\author{
Thomas P. West \\ Department of Biology and Microbiology, South Dakota State University, Brookings, SD 57007, USA \\ Correspondence should be addressed to Thomas P. West, thomas.west@sdstate.edu
}

Received 13 July 2012; Accepted 30 August 2012

Academic Editors: I. Berber and G. Blaiotta

Copyright () 2012 Thomas P. West. This is an open access article distributed under the Creative Commons Attribution License, which permits unrestricted use, distribution, and reproduction in any medium, provided the original work is properly cited.

The anion exchanger phosphocellulose and the cation exchanger triethylaminoethyl cellulose were used to immobilize cells of the fungus Aureobasidium pullulans ATCC 201253 and the adsorbed cells were subsequently investigated for their ability to produce the polysaccharide pullulan using batch fermentation. The cells adsorbed on the triethylaminoethyl cellulose at $\mathrm{pH} 7.5 \mathrm{produced}$ higher pullulan levels than those cells immobilized on phosphocellulose at $\mathrm{pH} 4.0$ for 2 cycles of $168 \mathrm{~h}$ at $30^{\circ} \mathrm{C}$. Relative to the initial cycle of $168 \mathrm{~h}$, pullulan production by the cells immobilized on the triethylaminoethyl cellulose decreased slightly after $168 \mathrm{~h}$ of the second production cycle while pullulan production by the phosphocellulose-immobilized cells remained about the same after $168 \mathrm{~h}$ of the second production cycle.

\section{Introduction}

Pullulan is an extracellular polysaccharide synthesized by the fungus Aureobasidium pullulans utilizing an excess of carbon with limiting nitrogen present [1-4]. The polysaccharide consists of primarily cross-linked maltotriose although a small proportion of maltotetraose residues has been detected in its structure [5-9]. Due to its high water solubility and low viscosity, pullulan has numerous commercial applications including its use as a food additive, a flocculant, a blood plasma substitute, an adhesive, and a film $[8,10,11]$.

Immobilization of $A$. pullulans cells by adsorption onto solid supports has been examined in previous studies. The advantage of using immobilized cells is that they can be used for more than a single cycle of polysaccharide production. When A. pullulans ATCC 42023 cells were immobilized by adsorption onto the solid support diatomaceous earth, the immobilized cells produced pullulan and were capable of being reutilized for a second cycle of pullulan production [12, 13]. Similarly, A. pullulans ATCC 42023 cells adsorbed onto sponge cubes were capable of several cycles of polysaccharide production [14]. Entrapped cells of A. pullulans can also be utilized to produce pullulan for at least two production cycles $[15,16]$. A biofilm reactor using a plastic composite support found that pullulan production by immobilized A. pullulans ATCC 201253 cells was maximal at $\mathrm{pH} 5.0$ after $168 \mathrm{~h}$ [17]. Ion exchange resins, such as DEAE (diethylaminoethyl) cellulose and ECTEOLA (epichlorohydrin triethanolamine) cellulose, have been utilized to adsorb corn syrup-grown cells of $A$. pullulans ATCC 42023, and the adsorbed cells produced pullulan for two production cycles $[13,18,19]$. The cells of the reduced pigmentation mutant strain A. pullulans ATCC 201253 have been adsorbed onto ion exchange resins and investigated relative to pullulan production $[18,20]$. It was found that ATCC 201253 cells could be adsorbed at pH 2.0 onto ion exchangers to produce pullulan from corn syrup [18].

In this study, pullulan production by corn syrup-grown cells of A. pullulans ATCC 201253 immobilized by adsorption onto the anion exchange resin phosphocellulose at $\mathrm{pH} 4.0$ or the cation exchange resin TEAE (triethylaminoethyl) cellulose at pH 7.5 using batch fermentation was compared. The effectiveness of utilizing the fungal cells adsorbed onto the ion exchangers for more than one cycle of batch pullulan production was also compared.

\section{Materials and Methods}

2.1. Strain and Media. Aureobasidium pullulans ATCC 201253 was the strain used in this work [20]. The 
composition of the culture medium was previously described [21]. In the phosphate-buffered medium, corn syrup served as the carbon source at a final concentration of $2.5 \%(\mathrm{w} / \mathrm{v})$ while ammonium sulfate served as the nitrogen source at a final concentration of $0.06 \%(\mathrm{w} / \mathrm{v})$. After inoculating batch cultures $(50 \mathrm{~mL})$ with overnight cultures $(0.5 \mathrm{~mL})$ grown in the same culture medium, each batch culture was shaken at $200 \mathrm{rpm}$ for $48 \mathrm{~h}$ at $30^{\circ} \mathrm{C}$.

2.2. Cell Immobilization on Ion Exchangers. Phosphocellulose or TEAE cellulose ( $1 \mathrm{~g}$ ) was pretreated by sequentially washing with $200 \mathrm{~mL}$ of $0.25 \mathrm{~N} \mathrm{HCl}$ and $0.25 \mathrm{~N} \mathrm{NaOH}$ in a sterile $250 \mathrm{~mL}$ Erlenmeyer flask. The resins were then resuspended in $0.5 \mathrm{~N} \mathrm{HCl}(200 \mathrm{~mL})$ overnight to sterilize them $[22,23]$. Following washing the resins at least three times with sterile water $(200 \mathrm{~mL})$, the water was removed from the resins and the resins could be utilized for cell adsorption. Phosphocellulose was suspended in $50 \mathrm{~mL}$ of culture medium ( $\mathrm{pH} 4.0)$ containing $2.5 \%(\mathrm{w} / \mathrm{v})$ corn syrup while the TEAE cellulose was suspended in $50 \mathrm{~mL}$ of culture medium ( $\mathrm{pH}$ 7.5). After each suspension was inoculated with medium containing about $10^{5}$ fungal cells/mL (from $48 \mathrm{~h}$ batch cultures), each flask was shaken (100 rpm) for $48 \mathrm{~h}$ at $30^{\circ} \mathrm{C}$. Each ion exchange resin with the adsorbed fungal cells was collected by low-speed centrifugation and washed twice with $0.85 \% \mathrm{NaCl}$. After each resin was suspended in $50 \mathrm{~mL}$ of culture medium ( $\mathrm{pH} 6.0)$ containing $2.5 \%(\mathrm{w} / \mathrm{v})$ corn syrup, the immobilized cells in the flasks were shaken $(125 \mathrm{rpm})$ for $168 \mathrm{~h}$ at $30^{\circ} \mathrm{C}$. Pullulan production by fungal cells immobilized at $\mathrm{pH} 4.0$ on phosphocellulose or at $\mathrm{pH} 7.5$ on TEAE cellulose was monitored at $24 \mathrm{~h}$ intervals. Following the first cycle of $168 \mathrm{~h}$, each cellulosic ion exchanger was collected by low-speed centrifugation, washed, and again suspended in culture medium ( $\mathrm{pH} 6.0)$ containing $2.5 \%(\mathrm{w} / \mathrm{v})$ corn syrup. The cultures were shaken $(125 \mathrm{rpm})$ for a second cycle of $168 \mathrm{~h}$ at $30^{\circ} \mathrm{C}$ during which the pullulan levels were measured at an interval of $24 \mathrm{~h}$.

2.3. Assays and Statistical Analysis. To monitor polysaccharide production, culture medium $(2 \mathrm{~mL})$ was removed and the sample was centrifuged $\left(14,600 \mathrm{~g}, 30 \mathrm{~min}, 4^{\circ} \mathrm{C}\right)$ with the supernatant being used for the pullulan determinations. To one volume of the pullulan-containing supernatant, two volumes of $95 \%$ ethanol were added to precipitate the polysaccharide. The precipitated pullulan was collected on $0.45 \mu \mathrm{m}$ HVLP filters ( $25 \mathrm{~mm}$ diameter). All filters were dried to constant weight at $105^{\circ} \mathrm{C}$ and reweighed to determine pullulan concentrations [21]. The viable fungal cell concentration of the adsorbed cells on each ion exchange resin was determined as stated previously [18]. Pullulan concentrations were expressed as $\mathrm{g} / \mathrm{l}$ and represent the mean of three independent determinations. The Student's $t$-test was used during statistical analysis.

\section{Results and Discussion}

Culture medium $\mathrm{pH}$ has been shown to affect fungal cell adsorption onto the ion exchange resins DEAE cellulose, phosphocellulose, TEAE cellulose, and ECTEOLA cellulose

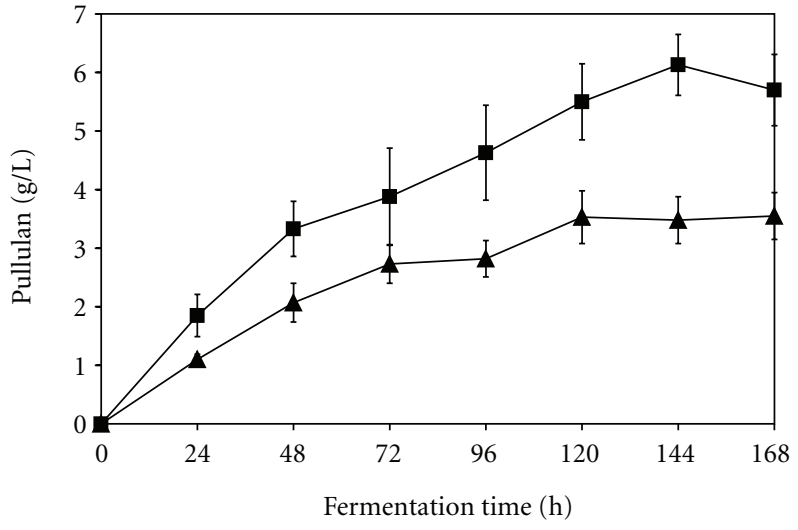

Figure 1: Pullulan levels (g/l) produced over a period of $168 \mathrm{~h}$ during cycle 1 by Aureobasidium pullulans ATCC 201253 cells adsorbed on triethylaminoethyl cellulose $(\boldsymbol{\square})$ or phosphocellulose $(\boldsymbol{\Delta})$. Error bars indicate the standard deviations of mean data values.

$[13,18,19]$. The culture medium $\mathrm{pH}$ used to adsorb the A. pullulans ATCC 201253 cells onto the resins was 2.0 which was based upon observed pullulan production by the immobilized cells incubated in medium ( $\mathrm{pH}$ 6.0) containing 3\% corn syrup $[13,19]$. In this study, it was determined that a higher concentration of cells could be adsorbed when the culture medium $\mathrm{pH}$ was elevated. The concentration of ATCC 201253 cells adsorbed at pH 4.0 onto the phosphocellulose was determined to be $1.4 \times 10^{5} \pm 0.9 \times 10^{5}$ (mean \pm standard deviation) colony-forming units/mg dry weight of resin which is higher than the concentration of $3.2 \times 10^{4} \pm 0.1 \times 10^{4}$ (mean \pm standard deviation) colonyforming units/mg dry weight of resin noted previously for adsorption onto phosphocellulose at pH 2.0 [18]. Similarly, the concentration of ATCC 201253 cells adsorbed at pH 7.5 onto the TEAE cellulose was found to be $5.4 \times 10^{6} \pm 6.5 \times 10^{6}$ (mean \pm standard deviation) colony-forming units/mg dry weight of resin which is higher than the concentration of $1.2 \times 10^{5} \pm 0.1 \times 10^{5}$ (mean \pm standard deviation) colonyforming units/mg dry weight of resin observed previously for adsorption onto TEAE cellulose at $\mathrm{pH} 2.0$ [18]. With the concentration of adsorbed cells being increased by elevating the culture medium $\mathrm{pH}$ used for cell adsorption, it was of interest to compare pullulan production by ATCC 201253 cells adsorbed onto phosphocellulose at $\mathrm{pH} 4.0$ and onto TEAE cellulose at $\mathrm{pH}$ 7.5.

With respect to both ion exchange resins, the ability of the immobilized cells to produce pullulan when incubated in medium ( $\mathrm{pH}$ 6.0) containing 3\% corn syrup during the initial cycle of polysaccharide production for $168 \mathrm{~h}$ using batch fermentation was investigated. As can be seen in Figure 1, the cells adsorbed on phosphocellulose produced pullulan after $24 \mathrm{~h}$ and continued to produce it for $120 \mathrm{~h}$ during the initial cycle of production. Pullulan production by the cells adsorbed on TEAE cellulose was noted after $24 \mathrm{~h}$ and continued to be produced for $144 \mathrm{~h}$ during the initial cycle of production (Figure 1). Pullulan production by the immobilized cells appeared to increase little after $144 \mathrm{~h}$ for cells adsorbed on either ion exchanger (Figure 1). 


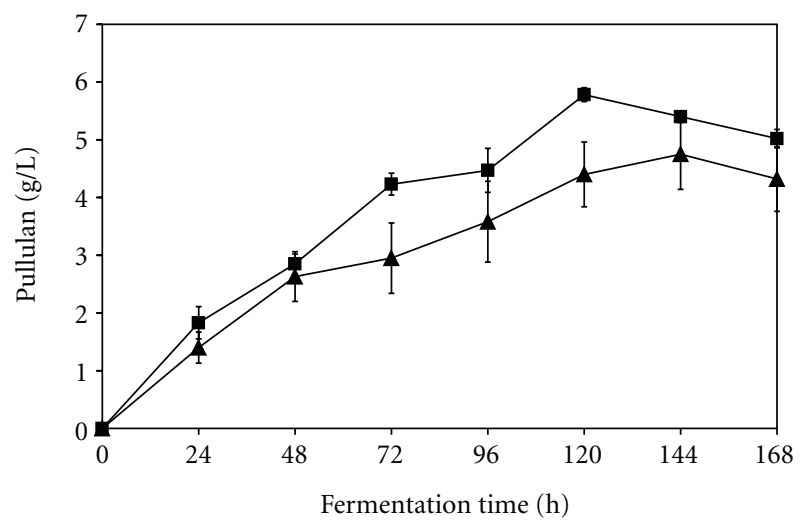

Figure 2: Pullulan levels (g/l) produced over a period of $168 \mathrm{~h}$ during cycle 2 by Aureobasidium pullulans ATCC 201253 cells adsorbed on triethylaminoethyl cellulose $(\boldsymbol{\square})$ or phosphocellulose $(\boldsymbol{\Delta})$. Error bars indicate the standard deviations of mean data values.

The pullulan levels produced during the initial cycle of $168 \mathrm{~h}$ by the cells adsorbed onto TEAE cellulose were higher than the polysaccharide levels produced by the cells adsorbed onto phosphocellulose (Figure 1). The difference in pullulan production after $96 \mathrm{~h}, 120 \mathrm{~h}, 144 \mathrm{~h}$, and $168 \mathrm{~h}$ between the cells adsorbed onto phosphocellulose at $\mathrm{pH} 4.0$ and the cells adsorbed onto TEAE cellulose at $\mathrm{pH} 7.5$ was statistically significant $(P<0.01)$. As can be seen in Figure 2, pullulan levels produced during the second cycle of $168 \mathrm{~h}$ by the cells adsorbed onto TEAE cellulose were higher than the polysaccharide levels produced by the cells adsorbed onto phosphocellulose which was also noted during the initial cycle of production. The difference in pullulan production after $120 \mathrm{~h}$ between the cells adsorbed onto phosphocellulose at $\mathrm{pH} 4.0$ and the cells adsorbed onto TEAE cellulose at $\mathrm{pH} 7.5$ was statistically significant $(P<0.01)$. For the cells adsorbed on the phosphocellulose or TEAE cellulose, there was no statistical difference in pullulan production after $168 \mathrm{~h}$ between the first and second production cycle. It appeared that pullulan production by the immobilized cells on either ion exchanger was equally effective for two cycles of production for $168 \mathrm{~h}$. The pH 4.0-adsorbed ATCC 201253 cells onto phosphocellulose used in this study produced less polysaccharide than the $\mathrm{pH}$ 2.0-adsorbed cells on phosphocellulose during the initial production cycle of $168 \mathrm{~h} \mathrm{[18].} \mathrm{In} \mathrm{contrast,} \mathrm{the} \mathrm{pH}$ 4.0-adsorbed ATCC 201253 cells used in this work produced higher polysaccharide levels on phosphocellulose than the $\mathrm{pH} 2.0$-adsorbed cells during the second production cycle of $168 \mathrm{~h} \mathrm{[18].} \mathrm{The} \mathrm{pH} \mathrm{7.5-adsorbed} \mathrm{ATCC} 201253$ cells on TEAE cellulose used in this study produced higher polysaccharide levels than the $\mathrm{pH}$ 2.0-adsorbed cells on phosphocellulose during both production cycles of $168 \mathrm{~h}$ [18].

Prior studies have investigated the immobilization of $A$. pullulans ATCC 42023 cells using the ion exchange resins DEAE cellulose or ECTEOLA cellulose and the ability of the immobilized cells to produce pullulan using batch fermentation $[13,19]$. ATCC 42023 cells were adsorbed onto DEAE cellulose or ECTEOLA cellulose at pH $2.0[13,19]$. Pullulan production by the ATCC 201253 cells adsorbed on TEAE cellulose used in this study was more similar to production by the DEAE cellulose-adsorbed ATCC 42023 cells than the ECTEOLA cellulose-adsorbed ATCC 42023 cells since the second cycle of production was lower than the initial production cycle $[13,19]$. Although the findings from this study showed that the phosphocellulose-adsorbed cells produced less polysaccharide than ECTEOLA celluloseadsorbed cells, pullulan production by the ECTEOLA cellulose-adsorbed cells was similar to pullulan production by the phosphocellulose adsorbed cells because pullulan levels decreased relatively little during the second production cycle compared to the initial production cycle [19].

\section{Conclusions}

The cation exchanger TEAE cellulose appeared to be a more effective adsorption support to immobilize A. pullulans ATCC 201253 cells when the cells were adsorbed at pH 7.5 instead of $\mathrm{pH}$ 2.0. The anion exchanger phosphocellulose was less effective than TEAE cellulose for pullulan production by ATCC 201253 cells independent of whether adsorption occurred at pH 2.0 or 4.0. The ATCC 201253 cells adsorbed at $\mathrm{pH} 4.0$ onto phosphocellulose were able to produce pullulan at comparable levels during both production cycles unlike the $\mathrm{pH}$ 2.0-adsorbed ATCC 201253 cells where pullulan production diminished during the second production cycle. Further study of $A$. pullulans cell immobilization using anion and cation exchangers for pullulan production will be necessary to identify the most effective ion exchanger that adsorbs high fungal cell concentrations and produces high pullulan levels for several cycles.

\section{Acknowledgments}

This work was supported by funds from the South Dakota AES and from US Department of Agriculture Grant no. 9437501-0884 and NIFA Grant no. 2011-67010-20051. The technical assistance of Beth Nemmers was greatly appreciated.

\section{References}

[1] B. Bernier, "The production of polysaccharides by fungi active in the decomposition of wood and forest litter," Canadian Journal of Microbiology, vol. 4, no. 3, pp. 195-204, 1958.

[2] S. Ueda, K. Fujita, K. Komatsu, and Z. Nakashima, "Polysaccharide produced by the genus Pullularia. I. Production of polysaccharide by growing cells," Applied Microbiology, vol. 11, no. 5, pp. 211-215, 1963.

[3] B. J. Catley, "Utilization of carbon sources by Pullularia pullulans for the elaboration of extracellular polysaccharides," Applied Microbiology, vol. 22, no. 4, pp. 641-649, 1971.

[4] R. F. Sena, M. C. Costelli, L. H. Gibson, and R. W. Coughlin, "Enhanced production of pullulan by two strains of $A$. pullulans with different concentrations of soybean oil in sucrose solution in batch fermentations," Brazilian Journal of Chemical Engineering, vol. 23, no. 4, pp. 507-515, 2006.

[5] W. Sowa W, A. C. Blackwood, and G. A. Adams, "Neutral extracellular glucan of Pullularia pullulans (de Bary) Berkhout," Canadian Journal of Chemistry, vol. 41, no. 9, pp. 2314-2319, 1963. 
[6] B. J. Catley, "Pullulan, a relationship between molecular weight and fine structure," FEBS Letters, vol. 10, no. 3, pp. 190 193, 1970.

[7] R. Taguchi, Y. Kikuchi, Y. Sakano, and T. Kobayashi, "Structural uniformity of pullulan produced by several strains of Pullularia pullulans," Agricultural and Biological Chemistry, vol. 37, no. 7, pp. 1583-1588, 1973.

[8] J. E. Zajic and A. LeDuy, "Flocculant and chemical properties of a polysaccharide from Pullularia pullulans," Applied Microbiology, vol. 25, no. 4, pp. 628-635, 1973.

[9] B. J. Catley, A. Ramsay, and C. Servis, "Observations on the structure of the fungal extracellular polysaccharide, pullulan," Carbohydrate Research, vol. 153, no. 1, pp. 79-86, 1986.

[10] R. S. Singh, G. K. Saini, and J. F. Kennedy, "Pullulan: microbial sources, production and applications," Carbohydrate Polymers, vol. 73, no. 4, pp. 515-531, 2008.

[11] K. C. Cheng, A. Demirci, and J. M. Catchmark, "Pullulan: biosynthesis, production, and applications," Applied Microbiology and Biotechnology, vol. 92, no. 1, pp. 29-44, 2011.

[12] A. Mulchandani, J. H. T. Luong, and A. LeDuy, "Biosynthesis of pullulan using immobilized Aureobasidium pullulans," Biotechnology and Bioengineering, vol. 33, no. 3, pp. 306-312, 1989.

[13] T. P. West and B. R. H. Strohfus, "Use of adsorption in immobilizing fungal cells for pullulan production," Microbios, vol. 85, no. 343, pp. 117-125, 1996.

[14] T. P. West and B. R. H. Strohfus, "Polysaccharide production by sponge-immobilized cells of the fungus Aureobasidium pullulans," Letters in Applied Microbiology, vol. 22, no. 2, pp. 162-164, 1996.

[15] T. P. West, "Pullulan production by Aureobasidium pullulans cells immobilized in chitosan beads-fungal pullulan production by immobilized cells," Folia Microbiologica, vol. 56, no. 4, pp. 335-338, 2011.

[16] T. P. West, "Effect of carbon source on polysaccharide production by alginate-entrapped Aureobasidium pullulans ATCC 42023 cells," Journal of Basic Microbiology, vol. 51, no. 6, pp. 673-677, 2011.

[17] K. C. Cheng, A. Demirci, and J. M. Catchmark, "Effects of plastic composite support and $\mathrm{pH}$ profiles on pullulan production in a biofilm reactor," Applied Microbiology and Biotechnology, vol. 86, no. 3, pp. 853-861, 2010.

[18] T. P. West and B. Strohfus, "Fungal cell immobilization on ion exchange resins for pullulan production," Microbios, vol. 88, no. 356, pp. 177-187, 1996.

[19] T. P. West, "Pullulan production by Aureobasidium pullulans cells immobilized on ECTEOLA-cellulose," Annals of Microbiology, vol. 60, no. 4, pp. 763-766, 2010.

[20] T. P. West and B. Reed-Hamer, "Polysaccharide production by a reduced pigmentation mutant of the fungus Aureobasidium pullulans," FEMS Microbiology Letters, vol. 113, no. 3, pp. 345349, 1993.

[21] T. P. West and B. Reed-Hamer, "Ability of Aureobasidium pullulans to synthesize pullulan upon selected sources of carbon and nitrogen," Microbios, vol. 67, no. 271, pp. 117-124, 1991.

[22] R. Bar, J. L. Gainer, and D. J. Kirwan, "Immobilization of Acetobacter aceti on cellulose ion exchangers: adsorption isotherms," Biotechnology and Bioengineering, vol. 28, no. 8, pp. 1166-1171, 1986.

[23] R. Bar, J. L. Gainer, and D. J. Kirwan, "Ethanol fermentation by ionically adsorbed Zymomomas mobilis: environmental effects on cell immobilization," Biotechnology and Bioengineering, vol. 29, no. 9, pp. 1045-1049, 1987. 

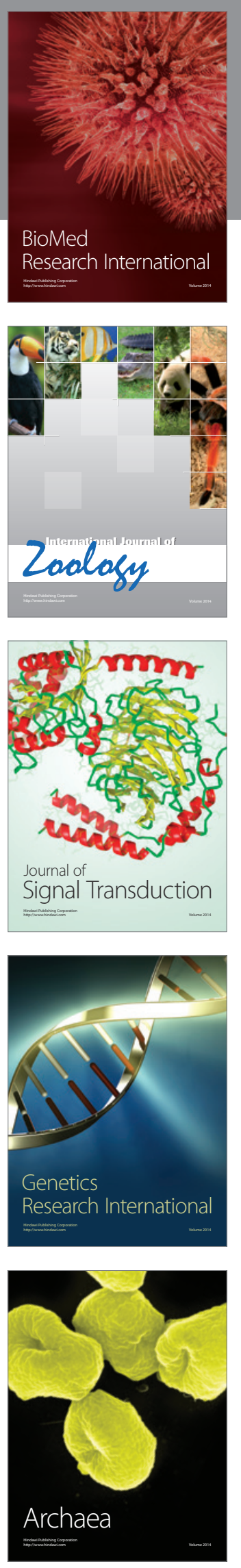
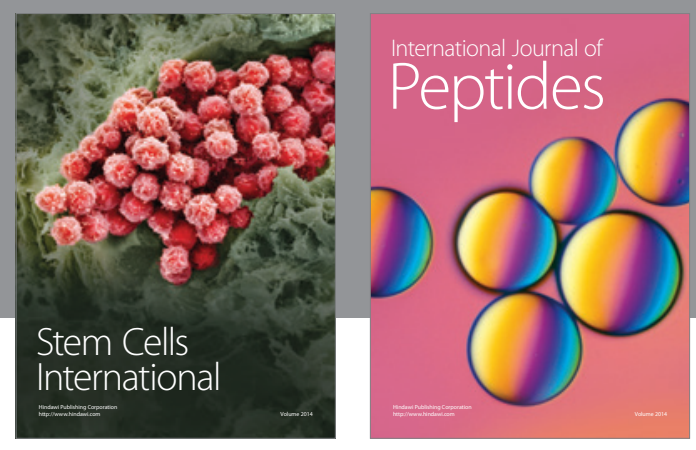

Submit your manuscripts at

http://www.hindawi.com
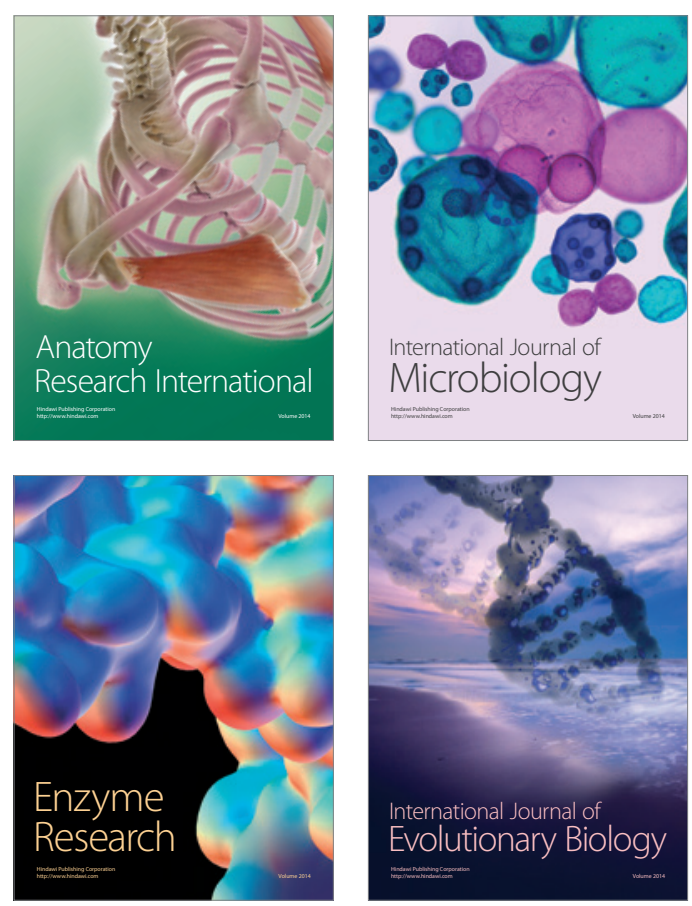
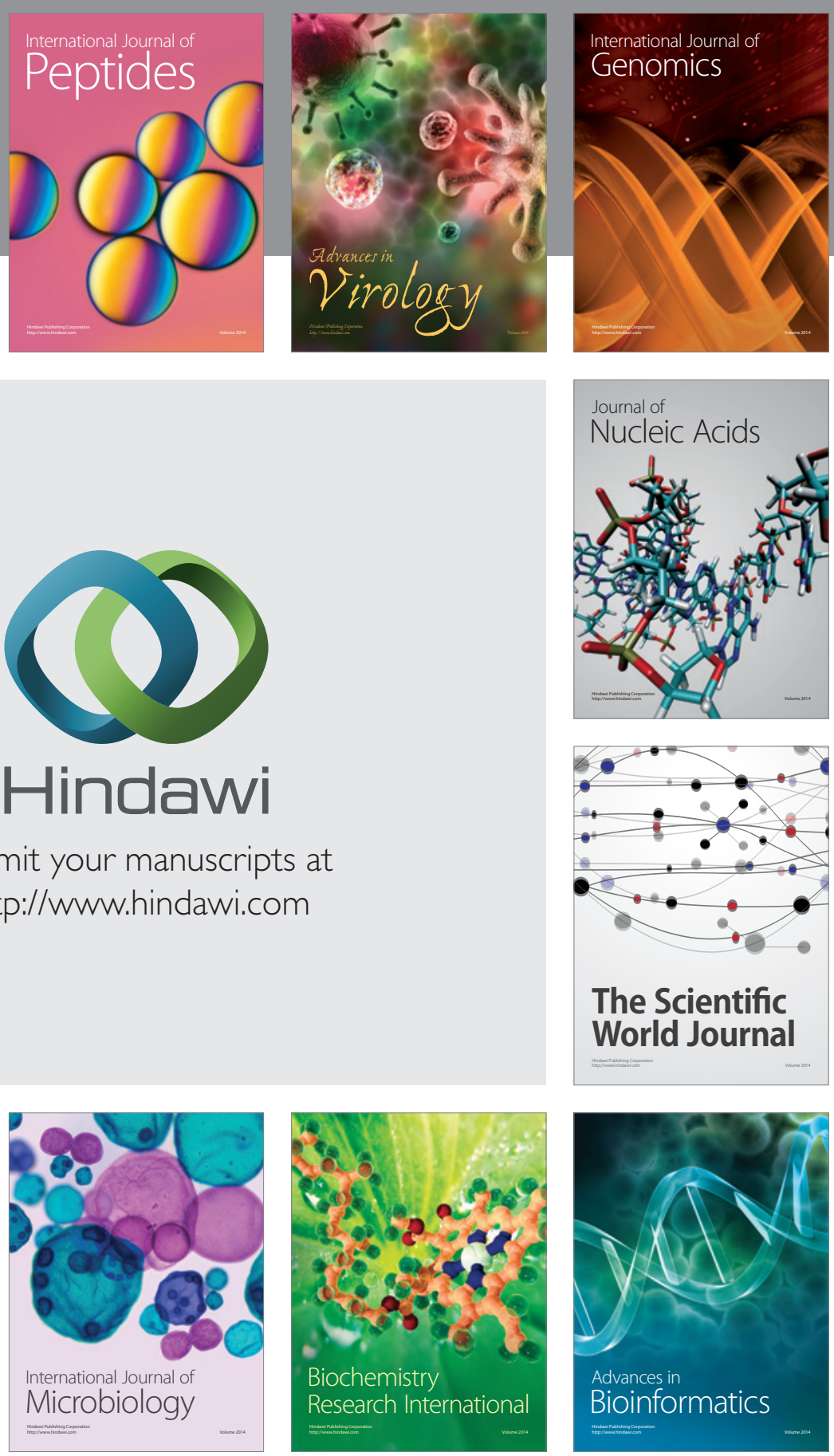

The Scientific World Journal
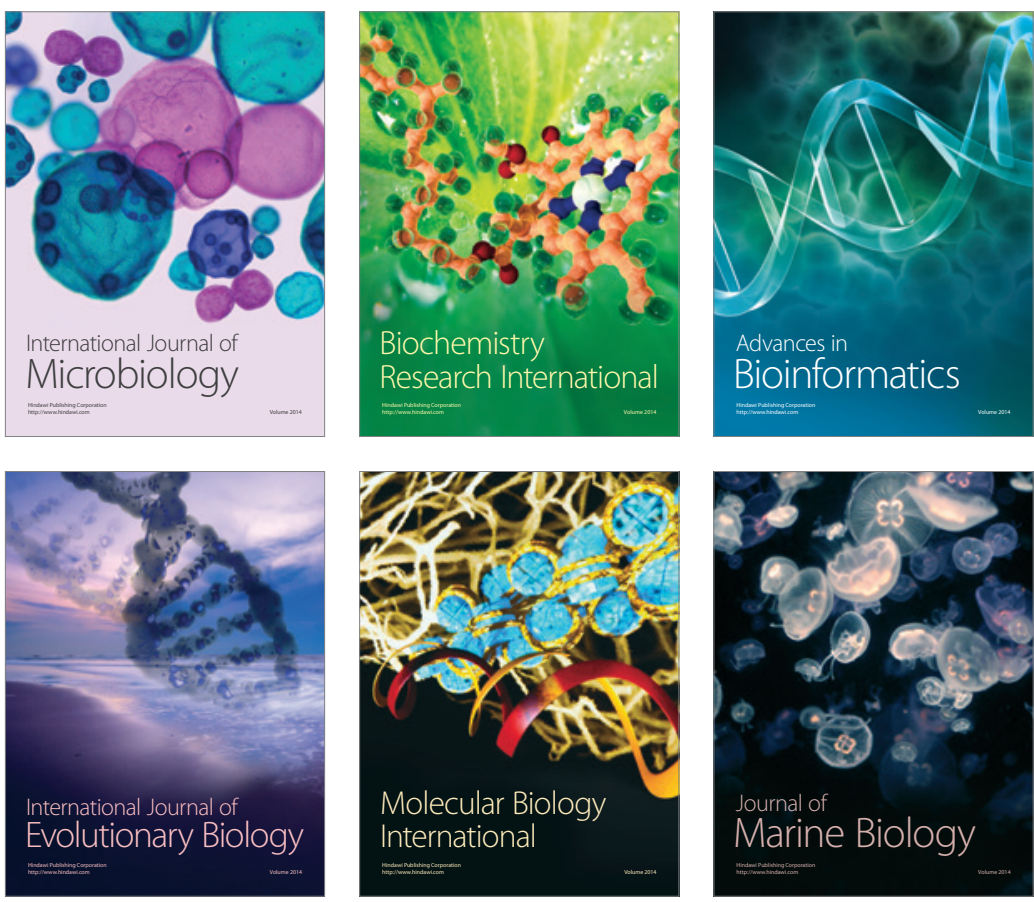